\title{
JAVANESE LANGUAGE AS AN ETHNIC IDENTITY MARKER AMONG MULTILINGUAL FAMILIES IN INDONESIA
}

\author{
Evynurul Laily Zen \\ Universitas Negeri Malang \\ evynurul.laily.fs@um.ac.id
}

\begin{abstract}
Abs tract
The rise of a pan-Indonesian national identity and the global significance of English have weakened heritage languages in Indonesia's various ethnolinguistic communities. Focusing on the case of Javanese, the largest ethnic group, this study examines the role of the HL as an ethnic marker and its interplay with factors such as ethnic self-identification, proficiency, and usage frequency. The data were collected via parental surveys of 183 primary school children in East Java. The findings indicate that the Javanese language is still highly valued as ethnic marker and that Javanese people view its maintenance as central to their identity construction. However, inconsistencies are identified between attitudes and practices, with use of Javanese as a home language decreasing, and children's production showing extensive influence from Indonesian. Taken together, positive attitudes regarding the Javanese as identity marker and the apparent ethnolinguistic vitality of Javanese is not necessarily translated into intergenerational transmission.
\end{abstract}

Keywords: Javanese, ethnic marker, language transmis sion, multilingual families

\begin{abstract}
Abstrak
Kebangkitan identitas nasional pasca kemerdekaan Indonesia dan signifikansi globalbahasa Inggris telah melemahkan peran dan fungsi bahasa daerah di berbagai kelompok etnis di Indonesia. Dengan mengambil studi kasus pada suku Jawa sebagai suku terbesar, penelitian ini bertujuan untuk mengkaji peran bahasa Jawa sebagai penanda suku serta keterkaitannya dengan berbagaifaktor, seperti identifikasi diriterhadap kelompok etnis Jawa, ketrampilan berbahasa Jawa, serta frekuensi penggunaannya. Data dalam penelitian ini dikumpulkan melalui metode survei terhadap 183 orang tua dari anak-anak usia sekolah dasar di Jawa Timur. Hasil survei menunjukkan bahwa orang tua dalam keluarga multibahasa masih mempersepsikan bahasa Jawa sebagai penanda etnis. Mereka juga masih memandang pemeliharaannya sebagai hal yang penting untuk membangun identitas kesukuan. Akan tetapi, penelitian inijuga menemukan ketidakselarasan antarapersepsidan praktik, di mana penggunaan bahasa Jawa di rumah mengalami penurunan drastis dan kemampuan berbahasa anak-anak menunjukkan adanya pengaruh luas dari bahasa Indonesia. Oleh karena itu dapat disimpulkan bahwa sikap positif masyarakat suku Jawa terhadap peran penting bahasa ini sebagai pemarkah etnis serta vitalitas etno linguistik bahasa Jawa tidak berbanding lurus dengan transmisibahasa Jawa kepada generasi berikutnya.
\end{abstract}

Kata kunci: Bahasa Jawa, pemarkah etnisitas, transmisi bahasa, keluarga multilingual

\section{INTRODUCTION}

In South East Asian societies where multilingualism has long become a norm rather than an exception, a highly dynamic multilingual ecology is often seen in light of competition among 
languages. Pivotal to this concern, studies on language maintenance and shift (LMS) have been blossoming in the academic arena (Pauwels, 2016). Factors that govern the linguistic choices among multilingual speakers become the driving force of LMS studies. There are tw o key settings pertinent to this area. Migrant setting and indigenous linguistic minority with the work of Susan Gal (1979) on language shift in Oberwart has widely been referred for the second setting. Attempting to enrich findings in non-migrant settings, Javanese as one of the indigenous heritage languages in Indonesia is taken under observation in this current study.

Unlike other cases where a particular ethnic group becomes a minority in their own territory with respect to the grow th of the majority, Javanese still retains a high ethno-linguistic vitality, both as an ethnic group and an ethnic language. As the largest ethnic group in Indonesia, Javanese was as large as $40.6 \%$ of the total population in 2010 and has the greatest number of first speakers in its home provinces of Central Java, Yogyakarta, and East Java as well as all over parts of the country due to internal migration (Ananta, Arifin, Hasbullah, Handayani, \& Pramono, 2015). However, a rapid decline of this number is apparent since 1990s following the changes of language-in-education policy with the official stipulation of Indonesian - or the so-called bahasa baku (Standard Indonesian) - as the language of instruction from kindergarten to university (Errington, 1998; Musgrave, 2014; Robson, 2004; Steinhauer, 1994). Massive spread and use of Indonesian in education, media, governmental administration, and other formal settings has stimulated a gradual shift of Javanese and other ethnic and local languages in all domains. Kurniasih (2006) pointed out an emerging pattern of home language use where middle class parents and children in Central Java province were in favor of using Indonesian; shifting aw ay Javanese from its use in private domains. Along this line, Putra (2018) discovered a great deal of challenging efforts undertaken by his young participants to find resources and opportunities to learn and use bahasa Lampung - a language spoken in the Lampung province of East Sumatra as almost everyone including their parents has shifted into using Indonesian at home due to a complex sociolinguistic dynamics in the region.

A trend of shift has essentially been recognized since the rise of a pan-Indonesian national identity after independence in 1945 along with the rise of global and regional significance of English throughout South East Asian countries that have weakened the role of ethnic languages including Javanese in Indonesia's various ethnolinguistic communities. Steinhauer (1994) reported the results of the 1980 and 1990 national census with an emphasis on a consistent decline of Javanese first speakers across different age groups (See Figure 1).

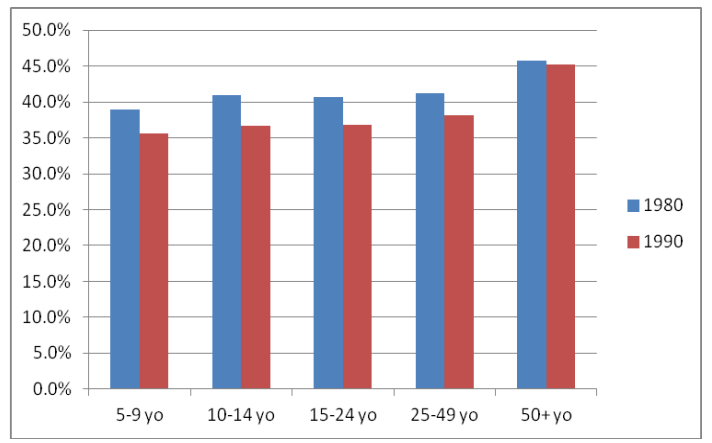

Figure 1: First-language s peakers of Javanese in the 1980 and 1990 national census 
In Figure 1, the highest drop occurs in the 10-14 age group. It puts forth an assumption that children are responsive to either rich or poor resources in the context of language acquisition and learning. Within a rich input to ethnic languages, they can experience an accelerated acquisition. On the contrary, when both internal and external environments fail to provide enough resources, children can be the first to move away from using minority language compared to adults who often indic ate a resistance toward either maintaining their ethnic and local languages. In other words, children's psychological behaviors are adaptable, often following the dominant group or whatever provided by their surrounding environments. In specific reference to how Javanese language thrives to survive among a tremendous grow th of Indonesian and English in the country, I aim to offer insights on Javanese maintenance and shift by looking carefully at the interplay between parental attitudes toward the role of Javanese as an ethnic marker and the Javanese proficiency of their children. With this objective at hand, this present study is geared toward an investigation of a long-held assumption on the role of attitudes in shaping language behavior (Wurm, 2002).

Extensive works have identified heritage and ethnic languages as to contain a strong indexical feature of ethnic identity (Mu \& Dooley, 2015). This conclusive assumption draws a critical role of language in an ethnic identity construction. Most of these works, however, investigate this relationship among immigrant communities. Kim and Chao (2010), for example, revealed that heritage language fluency has become a key player in the formation of ethnic identity for the second generation of Mexic an adolescents, but not for the second generation of Chinese group in the US. In a rather different migrant context in the US, Geerlings and Verkuyten (2015) pointed out that ethnic self-identification was found to influence heritage language preference in the Spanish speaking group, while language preference predicted ethnic self-identific ation among Asian communities. In addition, their study figured out that ethnic identification increased in adolescent, but heritage language preference decreased with age. In the UK setting, Farr, Blenkiron, Harris, and Smith (2018) illustrated a shift of ethnic identity construction among interethnic families with respect to their heritage language use in child-parent communication. These major w orks have provided a body of evidence on the link between heritage language and ethnic identity construction as well as how this linkage was translated into an inter-generational transmission of heritage language in migrant settings. Yet, little is know $\mathrm{n}$ about these dynamic relationships in the heritage language own territory among a rich and multifaceted multilingual situation.

As far as heritage and ethnic language transmission is concerned, studies have repeatedly found family as the most salient dimension of heritage language maintenance and loss. As King and Fogle (2013) suggested, heritage language usage in the family and among family members are the strongest predictor of language maintenance. Not only that it ensures the maintenance of heritage language, but it also empowers its speakers in building a closer inter-generational relationship, harmonious parent-adolescent communication, greater family solidarity, and better family well-being (Mu, 2015; Oh \& Fuligni, 2010; Tannenbaum \& Howie, 2002). With a relatively large body of literature in the field, however, there remains a need for further investigation especially in the contexts of heritage and ethnic languages in their homeland.

Focusing on the case of Javanese, this study addresses parental attitudes toward the role of Javanese language as an ethnic marker of Javanese society and its interplay with factors such as parental ethnic self-identification, children's ethnic language proficiency, and usage frequency of ethnic language in child-parent communication. The analysis is drawn from a larger 
investigation on the acquisition of Javanese as an ethnic language where interactions between proficiency and socio-ethnolinguistic variables have yielded a prominent result on the trend of sound shift among multilingual children in the Javanese speaking areas.

\section{FRAMEWORK}

Ethnic group is considered distinct from other social groups with regard to the existence of heritage language (Appel \& Muysken, 2005). Yucatán, Quintana Roo, and Campeche speaking Maya language in the Yucatan peninsula of Mexico is one to mention (Rhodes \& Bloechl, 2019), in addition to Madurese ethnic group in the island of Madura Indonesia speaking Madurese as home language (Ananta et al., 2015). In such a scenario, it is particularly important to underline Fishman's (1977: 25) view on the role of language as an emblem of ethnicity that functions as 'the recorder of paternity, the expresser of patrimony and the carrier of phenomenology'.

Following Fishman (2001), heritage language is broadly defined as immigrant, colonial and indigenous languages. In this context, Javanese fits into the category of indigenous or 'anc estral' and 'minority' language in Brutt-Griffler and Makoni's (2005) and De Bot and Gorter's (2005) terminology. Keeping the notion of 'linguistic minority' in mind, Javanese has gradually lost its prestige in the domain of everyday communication at the expense of Indonesian in which we can turn our question about repositioning Javanese as a marker of Javanese ethnic group in this present study.

With a focus on language, Smolicz and Secombe (1985) proposed a core value theory asserting that a group should possess a fundamental distinctive identifying value as the reflection of their identity. The theory was built upon extensive investigations on attitudes and language behaviors in various ethnolinguistic groups in Australia that resulted in a solid argument claiming that when a group sets a language as one of their core values, they will likely to put significant efforts to maintain it. Otherwise, they would be less concerned about its loss. In a similar vein, ethnolinguistic identity theory indicates the critical importance of language for ethnic identification because language is an inseparable part of ethnic experiences, so much so that without language, no ethnic and cultural activities could be conducted (Fishman, 1977; Giles, Bourhis, \& Taylor, 1977). Rakic, Steffens, and Mummendey (2011) provide support for this theory by proving the signific ant role of accents as auditory stimuli and looks as visual stimuli in an ethnic identification experiment conducted to the 42 college students in the Friedrich Schiller University Jena, Germany.

As far as ethnic identity is concerned, Giles's et al. (1977) theory of ethnolinguistic vitality is the most well-established framew ork to date. It describes that the degree of vitality of particular ethnic group determines their social behaviors in inter-group interactions. The theory also governs several variables of vitality including status (economic, social, socio-historical, and language status), demography (distribution and number of the population), and institutional support (formal and informal). Among these variables, it can be rightly argued that Javanese holds a high ethnolinguistic vitality using the data on its distribution, numbers, and language status from the national census alone (Ananta et al., 2015; Cobban, 1996).

Within a large body of scholarship on heritage language and ethnic identity, some of the major works have generated conclusive findings including that (1) heritage language fluency becomes an essential component of the ethnic identity for immigrant youth (Fishman, 1999; Kim $\&$ Chao, 2010), (2) minority languages are worth preserving because they represent unique and 
valuable national resource (Montrul, 2010), (3) two-way relationship is constantly found between heritage language and identity construction in which such a language often leads the process of identity construction and identity frequently helps heritage language maintenance ( $\mathrm{Mu}, 2015)$, and (4) heritage language has served as a symbol of cultural solidarity that embodies group feelings (Aida \& Gurin, 1995). These works, once again, paid most attention to migrant communities in which our study is projected to fill this gap in order to better understand a multilayer connection between heritage language and ethnic identity formation.

There has been a growing positive attitude tow ard heritage and ethnic languages across studies with a strong desire to transmit the languages to the next generations (Pauwels, 2016). Nevertheless, many parents found it challenging when it comes to commitment of use in daily communications for a number of reasons such as lack of institutional supports, individual confidence in speaking the language, and so forth (Bennett, 1990).

\section{METHOD}

This is a survey-based study where I look at parental attitudes tow ard Javanese language as an ethnic identity marker and whether these attitudes are translated into actual use of Javanese in home context as well as reasonable degree of proficiency in children. An online survey was distributed to 259 parents of primary school children in five public schools across East Java province. Only 183 were returned and then used in the analysis. By taking most concern on the linkage between language and ethnic identity, I adapted and simplified Phinney's (1992) Multigroup ethnic Identity Measure (MEIM) survey consisting of several elements; self-identification and ethnicity, ethnic behaviors and practices, affirmation and belonging, and identity achievement. By outlining five brief questions, I incorporated ethnic self-identification - $94 \%$ of the participants identified themselves as Javanese, perceived parental attitudes towards Javanese language proficiency as an ethnic marker and how it influences sense of belonging to the group, the critical importance of intergenerational transmission of Javanese, and regular use of Javanese at home, as well as the actual practices in parent-child's everyday communication. Prior to the completion of this survey, parents also completed language background questionaire (LBQ) scrutinizing bakcground information on their children's language use, self-assessed proviciency, and some other details.

I measured the Javanese language proficiency of the children under investigation using Mean Length of Utterance by Word (MLUw) method. This measurement w as carried out to assess two data sets: written storytelling and story retelling. These two experimental tasks were basically a part of a larger dissertation project that aimed at collecting evidence of cross-linguistic influence in third-language production among multilingual children in Indonesia. I used both descriptive statistics and $t$-test to analyze the interactions between ethnic language proficiency and other attitudinal variables.

\section{RESULTS AND DISCUSSION}

I will report and discuss the result of the survey under the following four sub-sections, namely: (a) attitudes on the linkage between Javanese proficiency and ethnic identity marker, (b) attitudes on intergenerational transmission of Javanese, (c) attitudes on Javanese use and its actual practices in the home environment, and (d) statistical interactions between children's Javanese proficiency and attitudinal variables. 


\section{Attitudes on Javanese proficiency and ethnic identity marker}

We first report the result illustrated in Figure 2 indicating that Javanese language is still highly valued as an ethnic marker. The act of self-identification as a member of Javanese ethnic group has necessarily to be translated into the ability of speaking the language. $85 \%$ of our participants agreed to this notion, 6\% disagreed, while 9\% were neutral (see the blue bar in Figure 2). This positive attitude is essential in LMS studies with special reference to the decisive role taken by families, as demonstrated in major works (see Caldas \& Caron-caldas, 2000; Leung \& Uchikoshi, 2012; Sari, Chasiotis, \& Vijver, 2018).

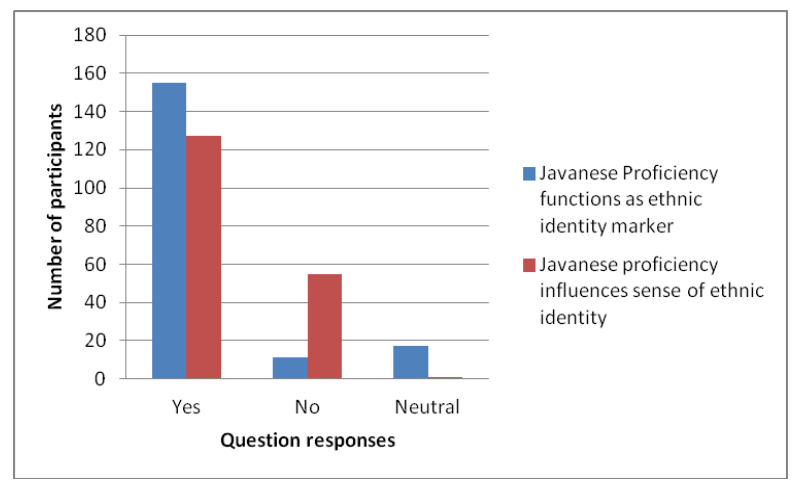

Figure 2: Javanese proficiency as ethnic identity marker

Attempting to confirm participants' attitudes and belief, we expanded the question into whether the absence of Javanese proficiency influences their sense of belonging to this ethnic community. The percentage of positive responses was considerably lower than the previous premise. Indicated by the red bar in Figure 2, 69\% perceived lack of Javanese proficiency would definitely determine their self-belonging. Along similar lines, Farr et al. (2018) maintained that heritage language fluency serves as a means of indexing ethnic memberships and facilitates a sense of belonging. To put it differently, group feelings are often more easily articulated when using the group's own language. Furthermore, language, as Appel and Muysken (2005) suggested, is instrumental not only in a message delivery, but also in cultural transmission process. In this way, the existence of heritage and ethnic languages become very meaningful in the whole process of ethnic identity formation as it carries norms, values, and feelings attributed to particular ethnic group. In the context of Mexican migrants in the US and Canada, Kim and Chao (2010) has drawn a similar finding where heritage language fluency and ethnic identity were intertwining in that heritage language loss went together with cultural identity loss. Latin Americans in Canada, according to their study, viewed heritage language transmission would ensure family unity and cultural identity. In these instances, heritage language proficiency for immigrant families does not simply work for verbal communication purposes among intergenerational members, but is also a representation of their ethnic identity (Fishman, 1977).

Looking back to my findings, how ever, I have to also consider the importance of $30 \%$ of those who perceived that being proficienct in Javanese is not crucial as with the lack of know ledge and fluency in Javanese, they still feel belonged to the Javanese ethnic group. Being born and raised as a Javanese remains true regardless the degree of fluency in the language. 


\section{Attitudes on intergenerational transmission of Javanese}

I take a positive attitude presented in the previous sub-section as a starting point to predict parents' desire and self-perceived importance of transmitting Javanese to their children. The prediction has been reinforced by the occurrence of greater number (85\%) of participants who wanted their children to learn and use Javanese in order to be able to identify themselves as a Javanese (See Figure 3).

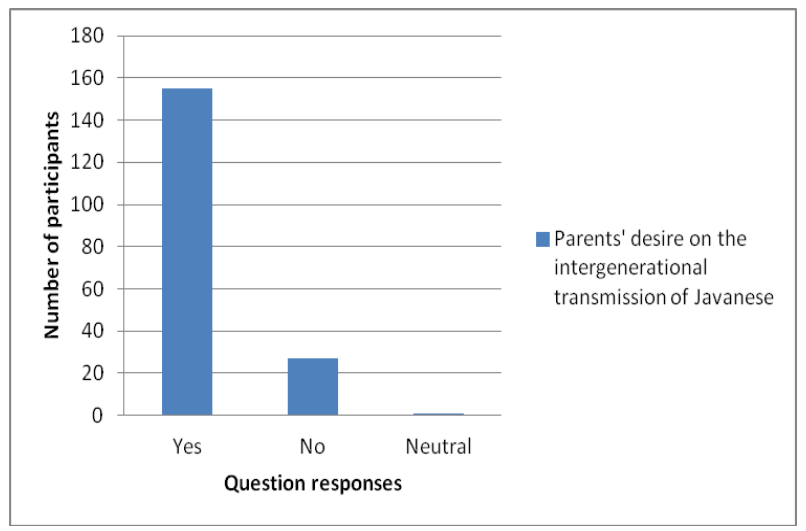

Figure 3: Parents' desire to transmit Javanese

This finding revealed the fact that Javanese people continue to view maintenance of the language as central to their identity construction so that they express a greater desire for the next generation to also be able to speak the language. As such, I refer to Appel and Muysken (2005) in maintaining that ethnic language has long embraced a strong position in family interaction and other informal domains, yet, the majority language often comes to interfere and sometimes to compete with it. Parents should, therefore, retain a good reason on why they still need to have this ethnic language transmitted. In this instance, preserving culturalidentity becomes one of the main factors as demonstrated in Guardado's (2002) study.

\section{Attitudes on the use of Javanese as home language}

$\mathrm{Mu}$ and Dooley's (2015) study provided evidence on a strong connection between family support and Chinese heritage language proficiency. This support is principally manifested in their commitment to use their heritage language as a major home language. In this respect, I attempted to compare parental attitudes tow ard the use of Javanese at home and its actual practic es. $60 \%$ of the parents claimed the importance of use of Javanese at home among family members (See the blue bar in Figure 4). This positive response is interestingly not as high as their perception toward the prominent role of Javanese as an ethnic marker as well as its transmission as elaborated in the previous subsection. This study has also identified inconsistencies between positive attitudes and actual practices where nearly a half of the parents (47\%) do not use Javanese in child-parent communication (See the red bar in Figure 4). This is consistent with findings from immigrant families where transmitting a heritage language also becomes a daily struggle due to social change (Farr et al., 2018). 


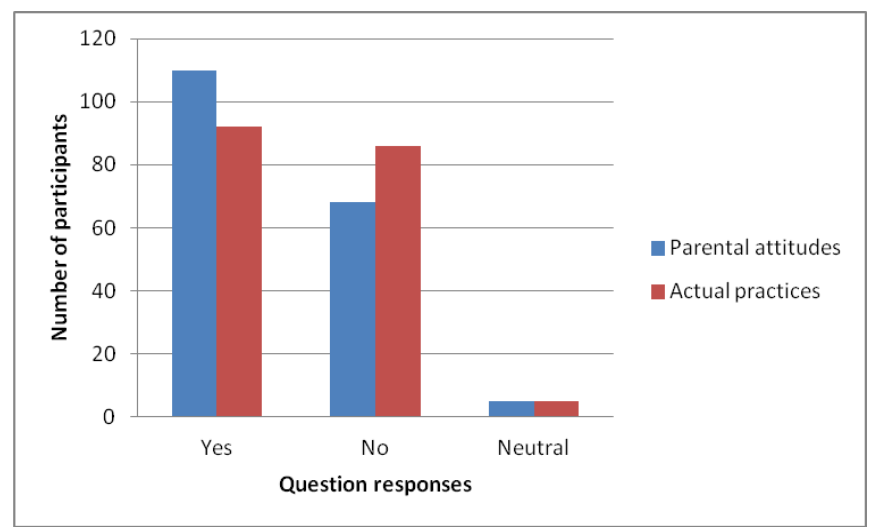

Figure 4: Attitudes and practices toward the use Javanese as home language

Taking a reflection on these findings, I argue that family should be attributed as a complementary element to ethnolinguistic vitality in the context of continuous use of heritage and ethnic languages. As shown in the national census data (Ananta et al., 2015; Cobban, 1996), a high vitality of Javanese as the largest ethnic group in Indonesia does not appear to correspond to a popular use of it in private spheres. In this circumstance, we expect to have family taking an active role as a gate keeper. How ever, it seems far from reality where only $51 \%$ of the parents are in a constant use of Javanese with their children.

In a careful analysis, Farr's et al (2018) study disc overed a different pattern. For a number of specific reasons, their Spanish speaking communities in the US have taken serious efforts in making intergenerational transmission of Spanish possible. Some of their participants felt their Spanish identity resurfaced when speaking their heritage language to their babies, while some others mentioned that they transmitted Spanish to their younger generations to bring back their familial roots and values. Keep in mind that this study was situated in a migrant setting where passing on cultural norms and values become more challenging due to lack of resources and environmental supports. It is therefore important to have in-group shared feeling maintained through the direct contact to their heritage language. Javanese in its territory is in contrast. I argue that being socially attributed as the majority has made Javanese people feel secure enough in practicing their cultural traditions with or without the presence of the language. However, this situation has caused disadvantages. Even with minimum efforts of maintaining the language, the Javanese ethnic group is still regarded as part of the majority.

In addition to analyzing attitudes, we carried out $t$-test to measure the interactions between children's Javanese proficiency and the aforementioned attitudinal variables of the parents. The results are summarized in Table 1 as follows. 
Table 1. Summary of interactions between Javanese children's proficiency and attitudinal variables

\begin{tabular}{llccl}
\hline Attitudinal Variables & $\begin{array}{l}\text { Std. } \\
\text { Error }\end{array}$ & $\boldsymbol{t}$ value & $\boldsymbol{p}$ value & Interpretation \\
\hline $\begin{array}{l}\text { Javanese proficiency as } \\
\text { ethnic identity marker }\end{array}$ & 0.328 & 0.9287 & 0.3543 & $\begin{array}{l}\text { Not statistically } \\
\text { significant }\end{array}$ \\
\hline $\begin{array}{l}\text { Javanese proficiency as } \\
\text { self-ethnic-identification }\end{array}$ & 0.257 & 0.3662 & 0.7146 & $\begin{array}{l}\text { Not statis tically } \\
\text { significant }\end{array}$ \\
\hline $\begin{array}{l}\text { Parents' desire to } \\
\text { transmit Javanese }\end{array}$ & $\mathbf{0 . 3 2 4}$ & $\mathbf{2 . 3 3 2 4}$ & $\mathbf{0 . 0 2 0 8}$ & $\begin{array}{l}\text { Statistically } \\
\text { significant }\end{array}$ \\
\hline $\begin{array}{l}\text { Importance of Javanese } \\
\text { as home language }\end{array}$ & $\mathbf{0 . 2 3 8}$ & $\mathbf{2 . 5 0 4 4}$ & $\mathbf{0 . 0 1 3 1}$ & $\begin{array}{l}\text { Statistically } \\
\text { significant }\end{array}$ \\
\hline $\begin{array}{l}\text { Actualpractices of } \\
\text { Javanese as home language }\end{array}$ & 0.235 & 1.8698 & 0.0631 & $\begin{array}{l}\text { Not quite statistically } \\
\text { significant }\end{array}$ \\
\hline
\end{tabular}

Parental positive attitude toward Javanese proficiency as an ethnic marker is statistically insignificant meaning that their perceived attitudes do not correspond to their children's proficiency. Interestingly, parents' desire both in transmitting Javanese as well as importance of using it at home is statistically significant to the level of proficiency their children have achieved. It particularly explains that the 'yes' responses correspond to a higher MLUw score but the actual practice of Javanese is surprisingly found not quite significant. Therefore, further in-depth exploration on typical pattern of parent-child verbal interaction deemed necessary to determine frequency of Javanese use in order to elucidate the underlying factors of why actual practices do not hold significant contribution to the children's proficiency. Understanding this linkage remains important because children's heritage language proficiency can sustain a rich inter-generational communication (Tannenbaum \& Howie, 2002), or else it can have a negative effect on family solidarity due to a weaker verbal contact (Oh \& Fuligni, 2010).

Decrease of Javanese use in family domains, we conclude from previous works, is due to several reasons; they are: language policy, urbanization, and internal linguistic factor. As abovementioned, heritage and ethnic languages have been offered as local-content subject in the primary school curriculum of Indonesia since 1990s. It denotes that these regional home languages are not only optional, but also limited to primary school levels with only 2 hours per week. This particular policy is in contrast to the global trends where identity has always been at the heart of education, mainly in heritage language classes (Leeman, Rabin, \& Roman-Mendoza, 2011). To put it differently, heritage language instruction is designed to cultivate students' aw areness to their own cultural ties where teachers should also possess cultural sensitivity to support heritage language development (Helmer, 2013). In Indonesian context, parents often find it irrelevant to support their children's heritage and ethnic language fluency as it may not be useful in the mainstream schools or in a specific national examination. It implies that when children are not proficient in their Javanese, they will still be able to achieve successful academic performance. In consequence, this lack of attention toward heritage language in schools and at homes may contribute to incomplete acquisition and loss of these languages as a result of insufficient input and exposure (Benmamoun, Montrul, \& Polinsky, 2013; Krashen, 1998). Moreover, minimum contact to heritage language resources both as formal school subject in classrooms and informal interaction with peers and families is often attributed to the decline of Javanese first speakers. 
This argument provides support for the signific ant role of social environment and network in the development of heritage languages among children (Cenoz \& Valencia, 2009).

I also intend to acknow ledge that the prevalence of Indonesian over ethnic languages has never been independent from the long history of nation-building of Indonesia. The process of national identity formation under a common wisdom of 'unity in diversity' that entails 'unified people', speaking 'one language', and living in 'one same homeland' through the declaration of Youth Oath (Sumpah Pemuda) back in 1928 has proclaimed Indonesian as the sole lingua franca which was followed by its constitutional recognition as the official language in 1945 (Errington, 1998). This has given a considerable impact particularly during the three decades of a heavyhanded language policy from 1966 to 1998 that has weakened the role of ethnic languages. During the supreme power of the New Order (Orde Baru), language planning and standardization has strengthened the role of Standard Indonesian as an important instrument of national development and modernization through the implementation of 'good and proper Indonesian' policy that at the same time ignored informal varieties and ethnic languages (Errington, 1998; Smith-hefner, 2007). In short, these historical lines have built a strong foundation of a 'common' identity among people with different ethnic backgrounds and all together imposed a secondary and minor role of ethnic languages after Indonesian. I put forw ard this argument in an attempt to understand the nature of inconsistencies we found between parental attitudes and actual practices. In this way, it becomes obvious that our finding provides support for Chhim and Bélanger's (2017) premise stating that with the absence of proficiency in a given language, people can still have opinion about its status as well as enjoy a sense of belonging to it. Furthermore, their study discovered that people's perception and belief toward Welsh and Irish in particular are not constrained with their ability and motivation to learn it.

A competing linguistic situation was also evident in a multicultural Botswana where the pronouncement of Setswana as the national language and English as the official language in educational instruction and wider contexts has marginalized other ethnic languages as well as subordinated the minorities (Boikhutso \& Jotia, 2013). In terms of attitudes toward ethnic groups, the Javanese have, indeed, undergone a contrasting situation where they still enjoy the privilege of being characterized as a national treasure and the largest ethnic community.

Finally, we should take urbanization and internal linguistic factor into account in the decrease of heritage and ethnic language uses. It is due to the advancement of information technology that inter-ethnic mobility becomes wide open making Indonesian language as a lingua franca is undeniably important (Ananta et al., 2015; Robson, 2004). This may shape parents' motivation in either maintaining or shifting ethnic languages by considering that communication in the $21^{\text {st }}$ century has gone beyond borders. Therefore, greater focus has been given to maintaining the proficiency in Indonesian and English or other foreign languages tends.

Internal linguistic factors of Javanese referring particularly to a complex speech level system have added a complication to its acquisition and development among children. Smithhefner (1983) argued that the younger generations tend to avoid using Javanese because of its speech levels that not only requires grammatical modification, but also politeness and cultural adjustment.

After all, we could not agree more to account that language is seen as central in all dimensions of identity, as Fishman (1977) suggested. Yet, identity itself is not fixed but instead are shaped by the macro- and micro-level socio-historic al contexts, including societal ideologies, 
power relations, and institutional politics (Leeman, 2015); an argument that deemed crucial in understanding the complex nature of our findings.

\section{CONCLUSIONS}

Close ties between migrants' ethnic identity and ethnic language use in different social contexts have extensively been substantiated. However, little is known about how this relationship manifests and develops in the territorial homeland of ethnic language, with special attention to a complex multilingual and multicultural environment of Indonesia. Putting scientific efforts to fill this gap, our study found that parents expressed a greater positive attitude tow ard the value of Javanese as an ethnic marker and maintained the importance of intergenerational transmission of the language. However, contradictions are identified between attitudes and practices, with actual use of Javanese as a home language decreasing. These findings, therefore, suggest that positive attitudes as well as apparent ethnolinguistic vitality of Javanese ethnic group are not necessarily translated into a continuous use of the language in private domains. In addition, parental attitudinal variables about ethnic language and ethnicity are statistically proven to be asymmetrical with children's Javanese proficiency, except that their desires in transmitting the language and perceived importance of Javanese use in home environments were seen to be symmetrical with children's high proficiency scores. Meanwhile, interactions between actual prac tic es of Javanese and its proficiency w ere surprisingly not quite statistically significant. Taken together, a body of evidence presented in this study with regard to the interactions among attitudes tow ard ethnic language, ethnicity, and constant use of ethnic language in Indonesian context are inseparable from a highly dynamic nature of historical, social, and political situation.

Future investigation looking at a multifaceted nature of heritage language and ethnic identity remains essential in various respects. One that may be of particular interest is on how urban-rural societies differ in the course of ethnic language maintenance and shift in which Appel and Muysken's (2005) finding has pointed out a tendency of rural group to preserve a minority language much longer than the urban. Any attempts taken to address this issue will advance our understanding and help predict the future trajectory of ethnic languages in multilingual Southeast Asia.

\section{NOTE}

The author would like to thank two anonymous reviewers for very helpful comments on the earlier draft.

\section{REFERENCES}

Aida, H., \& Gurin, P. (1995). Ethnic identity and bilingualism attitudes. In A. M. Padilla (Ed.), Hispanic psychology: Critical issues in theory and research (pp. 89-103). Thousand Oaks, California: Sage.

Ananta, A., Arifin, E. N., Hasbullah, M. S., Handayani, N. B., \& Pramono, A. (2015). Demography of Indonesia's Ethnicity. Singapore: ISEAS Publishing.

Appel, R., \& Muysken, P. (2005). Language contact and bilingualism. Amsterdam: Amsterdam Academic Archive. 
Benmamoun, E., Montrul, S., \& Polinsky, M. (2013). Defining an “ ideal " heritage speaker: Theoretical and methodological challenges Reply to peer commentaries. Theoretical Linguistics, 39(3-4), 259-294. https://doi.org/10.1515/tl-2013-0018

Bennett, J. E. (1990). Attitudes of the second generation Dutch to language maintenance and ethnic identity. Monash University.

Boikhutso, K. \& Jotia, A. L. (2013). Language identity and multicultural diversity in Botswana. International Journal of Lifelong Education, 32(6), 797-815. https://doi.org/10.1080/02601370.2013.814725

Brutt-Griffler, J., \& Makoni, S. (2005). The use of heritage language: Am Afric an perspective. Modern Language Journal, 89(4), 609-612.

Caldas, S. J., \& Caron-caldas, S. (2000). The influence of family, school, and community on bilingual preference: Results from a Louisiana/Quebec case study. Applied Psycholinguistics, 21, 365-381.

Cenoz, J., \& Valencia, J. F. (2009). Ethnolinguistic vitality , social networks and motivation in second language acquisition: Some data from the basque country, 8318. https://doi.org/10.1080/07908319309525143

Chhim, C., \& Bélanger, É. (2017). Language as a public good and national identity: Scotland's competing heritage languages. Nations and Nationalism. https://doi.org/10.1111/nana.12347

Cobban, J. L. (1996). Indonesia: Insular contrasts of the Java core with outer islands. In A. K. Dutt (Ed.), Southeas Asia: A ten nation region (pp. 135-152). The Netherlands: Kluwer Academic Publishers.

De Bot, K. \& Gorter, D. (2005). A European perspective on heritage languages. Modern Language Journal, 89(4), 612-616.

Errington, J. (1998). Shifting languages: Interaction and identity in Javanese Indonesia. Cambridge: Cambridge University Press.

Farr, J., Blenkiron, L., Harris, R., \& Smith, J. A. (2018). “It's my language, my culture, and it's personal!" Migrant mothers' experience of language use and identity change in their relationship with their children: An interpretative phenomenological analysis. Journal of Family Issues, 39(11), 3029-3054. https://doi.org/10.1177/0192513X18764542

Fishman, J. A. (1977). Language and ethnicity. In How ard Giles (Ed.), Language, ethnicity, and intergroup relations (pp. 15-57). New York: Academic Press.

Fishman, J. A. (1999). Handbook of language and ethnic identity. New York: Oxford University Press.

Fishman, J. A. (2001). Can threatened languages be saved? Clevedon, UK: Multilingual Matters.

Gal, S. (1979). Language shift: Social determinants of language shift in bilingual Austria. San Francisco, CA: Academic Press.

Geerlings, J., \& Verkuyten, M. (2015). Changes in Ethnic Self-Identification and Heritage Language Preference in Adolescence: A Cross-Lagged Panel Study. https://doi.org/10.1177/0261927X14564467

Giles, H., Bourhis, R. Y., \& Taylor, M. D. (1977). Tow ards a theory of language in ethnic group relations. In H. Giles (Ed.), Language, ethnicity, and intergroup relations (pp. 307-348). 
London: Academic Press.

Guardado, M. (2002). Loss and maintenance of first language skills: Case studies of Hispanic families in Vancouver. Canadian Modern Language Review, 58, 341-363.

Helmer, K. A. (2013). A twice-told tale: Voices of resistance in a borderlands. Anthropology Education Quarterly, 44(3), 269-285. https://doi.org/10.1111/aeq.12025

Kim, S. Y., \& Chao, R. K. (2010). Heritage language fluency, ethnic identity, and school effort of immigrant Chinese and Mexican adolescents. Cultural Diversity Ethnic Minor Psychology, 15(1), 27-37. https://doi.org/10.1037/a0013052.Heritage

King, K. a., \& Fogle, L. W. (2013). Family language policy and bilingual parenting. Language Teaching, 46(2), 172-194. https://doi.org/10.1017/S0261444812000493

Krashen, S. D. (1998). Heritage language development: Some practical arguments. In S. D. Krashen \& J. McQuillan (Eds.), Heritage language development (pp. 3-13). Culver City, California: Language Education Associates.

Kurniasih, Y. K. (2006). Gender, class and language preference: A case study in Yogyakarta. In K. Allan (Ed.), Selected papers from the 2005 Conference of the Asutralian Linguistic Society (pp. 1-25). Australian Linguistic Society. Retrieved from http://als.asn.au/proceedings/als2005/kurniasih-gender.pdf

Leeman, J. (2015). Heritage language education and identity in the United States. Annual Review of Applied Linguistics, 35, 100-119. https://doi.org/10.1017/S0267190514000245

Leeman, J., Rabin, L., \& Roman-Mendoza, E. (2011). Identity and activism in heritage language education. The Modern Language Journal, 95, 481-495. https://doi.org/10.1111/j.15404781.2011.01237.x

Leung, G., \& Uchikoshi, Y. (2012). Relationships Among Language Ideologies, Family Language Policies, and Children's Language Achievement: A Look at Cantonese-English Bilinguals in the U.S. Bilingual Research Journal, 35(3), 294-313. https://doi.org/10.1080/15235882.2012.731588

Montrul, S. (2010). Current issues in heritage language acquisition. Annual Review of Applied Linguistics, 30, 3-23. https://doi.org/10.1017/S0267190510000103

$\mathrm{Mu}, \mathrm{G} . \mathrm{M}$. (2015). A meta-analysis of the correlation between heritage language and ethnic identity. Journal of Multilingual and Multicultural Development, 36(3), 239-254. https://doi.org/10.1080/01434632.2014.909446

Mu, G. M., \& Dooley, K. (2015). Coming into an inheritance: Family support and Chinese heritage language learning. International Journal of Bilingual Education and Bilingualism, 18(4), 501-515. https://doi.org/10.1080/13670050.2014.928258

Musgrave, S. (2014). Language shift and language maintenance in Indonesia. In Language, Education and Nation-building (pp. 87-105).

Oh, J. S., \& Fuligni, A. J. (2010). The role of heritage language development in the ethnic identity and family relationships of adolescents from immigrant backgrounds. Social Development, 19(1), 202-220. https://doi.org/10.1111/j.1467-9507.2008.00530.x

Pauwels, A. (2016). Language maintenance and shift. Cambridge: Cambridge University Press.

Phinney, J. S. (1992). The multigroup ethnic identity measure: A new scale for use with diverse groups. Journal of Adolescent Research, 7(2), 156-176. 
Putra, K. A. (2018). Youth, technology and indigenous language revitalization in Indonesia. The University of Arizona.

Rakic, T., Steffens, M. C., \& Mummendey, A. (2011). Blinded by the accent! The minor role of looks in ethnic categorization. Journal of Personality and Social Psychology, 100(1), 1629. https://doi.org/10.1037/a0021522

Rhodes, C. R., \& Bloechl, C. (2019). Speaking Maya, Being Maya: Ideological and institutional mediations of language in contemporary Yucatan. In S. D. Brunn \& R. Kehrein (Eds.), Handbook of the changing world language map (pp. 1-23). Switzerland: Springer Nature Switzerland.

Robson, S. (2004). Welcome to Indonesian: A beginner's survey of the language. Singapore: Tuttle Publishing.

Sari, B. T., Chasiotis, A., \& Vijver, F. J. R. Van De. (2018). Parental culture maintenance, bilingualism, identity, and well-being in Javanese, Batak, and Chinese adolescents in Indonesia. Journal of Multilingual and Multicultural Development, 39(10), 853-867. https://doi.org/10.1080/01434632.2018.1449847

Smith-hefner, N. J. (1983). language and social identity: Speaking Javanese in Tengger. The University of Michigan.

Smith-hefner, N. J. (2007). Youth Language, Gaul Sociability, and the New Indonesian Middle Class. Journal of Linguistic Anthropology, 17(2), 184-203. https://doi.org/10.1525/jlin.2007.17.2.184.184

Smolicz, J. J., \& Secombe, M. (1985). Community languages, core values and cultural maintenance; the Australian experience with special reference to Greek, Latvian and Polish groups. In M. Clyne (Ed.), Australia: meeting place of languages (pp. 11-38). Canberra: Australian National University.

Steinhauer, H. (1994). The Indonesian language situation and linguistics: Prospects and possibilities. Bijdragen Tot de Taal-, Land-En Volkenkunde, 150(4), 755-784. Retrieved from http://www.jstor.org/stable/27864615

Tannenbaum, M., \& How ie, P. (2002). The association between language maintenance and family relations: Chinese immigrant children in Australia. Journal of Multilingual and Multicultural Development, 23(5), 408-424. https://doi.org/10.1080/01434630208666477

Wurm, S. (2002). Strategies for language maintenance and revival. In D. Bradley \& M. Bradley (Eds.), Language endangerment and language maintenance: An active approach (pp. 1123). 